\title{
Causes of Conflict and the Role of Indigenous Conflict Resolution Mechanism Among Degodia Clan: In Case of Dollo Addo District, Somali Region, South East Ethiopia
}

\author{
Abdinasir Barre Hassan \\ College of Social Science and Humanities, Department of Political Science and International Relations, Jigjiga University, Jigjiga, Ethiopia \\ Email address: \\ Abdinasirb4@gmail.com \\ To cite this article: \\ Abdinasir Barre Hassan. Causes of Conflict and the Role of Indigenous Conflict Resolution Mechanism Among Degodia Clan: In Case of \\ Dollo Addo District, Somali Region, South East Ethiopia. American Journal of Applied Psychology. Vol. 9, No. 4, 2020 , pp. 117-123. \\ doi: 10.11648/j.ajap.20200904.15
}

Received: July 14, 2020; Accepted: July 28, 2020; Published: August 5, 2020

\begin{abstract}
This study was conducted in Dollo Ado District with main objective of identifying the causes of conflict and the characteristic of the indigenous conflict resolution mechanism among Degodia clan of Dollo Ado district. As such, it is aimed to explore the source of conflict within the Degodia clan, identify the means of conflict resolution, its challenge as well as relation with modern institution. The study is designed qualitatively on the basis of primary source of data. The finding of the study shows that the source of conflict among Degodia clan are related to water point access, farmland, and women. Moreover, the study reveals that the Degodia clan traditional conflict resolution method remains more acceptable than the modern state law because it is easier to get the society elders than the government proceedings or it is cheaper, not time consuming with law cost. The finding of the study also shows that there are challenges faced the Degodia traditional conflict resolution strategy, which among others include financial problem and luck of support by the government locally. Finally, in order to minimize the source of conflict within the society, the study recommends that the government should work towards settling the people based on identified borders between the clans, distributing land ownerships for clan or even individuals levels, increasing access for water availability and realizing women equality with men in such as property ownership and marriage rights, to overcome the challenges faced by the traditional conflict resolution institution the government at local level or national levels should support the elders financially and in terms of training.
\end{abstract}

Keywords: Conflict, Indigenous, Conflict Resolution, Wabar System, Conflict Resolution

\section{Introduction}

Conflict is an unavoidable phenomenon in human life since the entire life of humankind is manipulated by the widespread of conflict within the society when people set opinion against opinion, run interest against interest [1]. The working definition of conflict is that; it is a social situation in which a minimum of two parties (actors) strives to acquire at the same movement in time an available set of scarce resources, which is difficult [2].

Conflict is defined as a confrontation between one or more parties aspiring towards incompatible or competitive means or ends [3]. Confrontation is a process that begins when one party observes that another party has undesirably affected or is about to negatively affect, something that the first party cares about.
Hence, attempting to avoid conflict is not only going against nature but it is also going against development [4].

According to Fiseha, it is conceivable to distinguish between the modern, more of the western oriented, school curriculum based and formally trained ways of conflict management and resolution mechanism and a traditional, more of cultural context oriented, and indigenous knowledge based conflict management and resolution mechanisms [5].

Every society has its own techniques of handling disputes [6]. The concept of 'indignity' implies institutions, methods and practices predating colonialism and the Westphalia state that derive from the sociological, historical, demographic, environmental and geographical locations in which they exist [7]. He further suggested that the role of indigenous institutions in conflict resolution as well as peace building is 
becoming increasingly prominent in parts of the world [7].

"According to (Osi, 2008), Indigenous Conflict Resolution processes," are important, practiced and pre-colonial methods and structures of dealing with community problems by coming up with a consensual, communal resolution. [8].

indigenous conflict resolution mechanisms, in general, are always centered on the values of truth, justice, forgiveness, reconciliation, addressing the affected relationship, voluntary participation and give more emphasis for personal change above complaint behavior [9].

He added that Indigenous methods to conflict resolution vary significantly from society to society, from region to region, from community to community. Indigenous conflict resolution instruments are locally organized institutions working bestowing to the custom and norms of given community and works according to the specific culture of certain society [9].

In Africa, household ties and community networking are constantly respected, maintained and strengthened. When there is a dispute between different groups, priority is given to restoring the relationships. The instant objective of such conflict resolution is to restore the broken or damaged relationship, and correct wrongs, and restore justice. Another aim is to guarantee the full combination of parties into their societies again and to adopt the mood of cooperation [10].

Ethiopia is believed to be the "museum of peoples" with more than 80 ethnic groups constituting and forming one nation state. It is a country of diversity sheltering varieties of languages, different religions and faiths as well as quite many nations and nationalities with their own ethical perspectives and unique cultural practices [11]. Conflicts in Ethiopia could easily be handled at the grass-root levels by the citizens themselves without the direct interference of the government [4].

In the Somali region there is an indigenous conflict resolution mechanism that has been in use since time immemorial and is still quite effective in resolving conflicts today [12]. Indigenous conflict resolution mechanisms remain widely favored and utilized; there is a welldeveloped, pretty planned conflict resolution mechanism in place in the region. The guurti elders are the judge and jury and their decisions are largely adhered to and respected. Somalis understand from a young age how conflicts are supposed to be resolved, the various steps in the process and what can happen if those steps are not followed [13].

Therefore, this study is carried to find out source and mechanisms of conflict resolution among this community, since there is no study conducted in the area concerning this case and perceptibly every community has its own conflict resolution mechanisms.

\section{Objective of the Study}

The general objective of this study is to examine causes of conflict and the characteristic of the indigenous conflict resolution mechanism among Degodia clan of Dollo Ado district.

\section{Methods and Materials}

\subsection{Description of the Study Area}

Dollo Ado district is one of the ninety-three districts in the Somali Regional State and is a part of zone Liban; it is located in the extreme south-western corner of the Somali region. The district is bordered by the Dollo Bay district of the Afdeer Zone of the Somali region in the north, Boqolmayo district in the north west and Somalia's Geddo region in east and Kenya's Mandera district in the south. According to the last census, carried out in 2015, the district has a total population of 174,992 out of which $49 \%$ are male and $51 \%$ are females [14].

\subsection{Study Design}

The approach used in this research is qualitative. Therefore; qualitative method of data collection such as key informant interview and group discussion has been used in this study.

\subsection{Sampling Procedure}

The proposed study used non-probability sample. The sample size was determined by using purposive sampling method due to time and limited resource. Three focus group discussions covering issues of community's perception of changes, traditional conflict resolution mechanisms, and challenges of the indigenous conflict resolution and social activities of the target population was examined in depth. The average number of respondents at each of the FGD was eight. This provided in-depth information regarding the perception of each group regarding a particular theme. Interviewing key informants and local residents in Dollo Ado district was the other important investigation technique applied during the field study, and findings from informant interviews carried out with local people in Dollo Ado district constitute the bearing data and have been the main engine behind the development of this thesis.

\subsection{Source of Data}

To achieve the objective of the research, data were collected from both primary sources. The following sections discuss issues related to source and techniques of data collection on.

\subsection{Primary Data Source}

A primary source of data has been gathered through different strategies. This includes interviews, focus group discussion, and key informant interviews. The study been using semi-structured interview, and the informants have been prominent elders from the Degodia community who have the experience and being decision makers in the indigenous conflict resolution institution, government official has been included who are working court and the other department at the Woreda. Key informant interview in order to get data on past events and scenarios and even on the current reality, the study been conduct key informant 
interview with the individuals who have the knowledge and experience of the indigenous conflict resolution mechanism. Thus, source of information been elders, clan and lineage leaders. The study also, conducted focus group discussion because on some specific issues different people may have different concerns. Thus, to look at concerns of different individuals and even to assess their level of understanding on some issue the researcher been conduct FGD with different groups in order to get their experience and knowledge in the study topic. Thus, informant has been Elders, women, young people and other levels, with those who engaged in the practice of the practice and beneficiary of indigenous conflict resolution mechanism.

\subsection{Method of Data Collection}

The method of data collection tool applied in this study was following focus group discussion (FGD), and interviews based on semi-structured questions. Targeted data sources participated in FGD and key informants for KII (Key informant Interviews) were purposively selected.

For all interviews, an interview guide was developed, yet all kept a semi-structured format. All interviews, both with key informants and focus group discussion, aimed at having a conversational style and encouraging interviewees to participate, as all interviews on top of seeking to cover a range of basic themes/questions as outlined in the interview guides, had a basic exploratory objective, aiming at learning more about the context at large.

\subsection{Data Analysis and Interpretation}

A qualitative data analysis is used. Descriptive methods of data analysis techniques were applied to analyze and interpret the qualitative data. Moreover, content analysis was used to clearly examine and identify the causes and characteristic of indigenous conflict resolution mechanism among Degodia community in Dollo Ado district. Therefore, qualitative data has been analyzed based on the theoretical and methodological principles of interpretation using narrative analysis technique.

\subsection{Validation of Data}

Before data collection the recorder was tested if it is working or not, then pretest was done for two individuals to check the validity of the interview questionnaire after that modification was done accordingly

\subsection{Ethical Issue}

Ethical clearance letter was obtained from Jigjiga University from research and ethics committee Therefore, the researcher considered the ethical standards of the host community that means on which the research has been conducted.

\section{Results}

In general, the sources and drivers for conflicts in the study area can be categorized in to three places. These are conflict over farm land, conflict on to water point's access, conflict on women. Conflict over resource of land and water points has been mostly characterized by temporary conflicts initially for access and use of resources for the last many years. This has become frequent in recent years due to drought, increasing of resource scarcity. Currently the conflict increased over water points and grazing land and access of farm land holding related conflicts in the study area.

\subsection{Source of Conflict Among the Degodia Clan}

\subsubsection{Farmland Related Disputes and Conflicts}

According to the data obtained from the elders, disputes over farmland occur among the Degodia clan which frequently occur in terms of ownership of farmland, and a border related issues of farmland. Conflict occurs on the ownership of the farmland, because the Degodia clan previously used to be pure pastoralist but due to the prolonged recurrent drought, and the other challenges they faced lead them to change their way of life thus resulted to dispute over ownership of farmland which sometimes caused conflict starting from individual and further leads to intraclan conflict. The other reason is related to border (Soohdin) on the farmland, because of weak demarcation and expansion of the land among the neighboring farmers always create dispute which may took a long period in order to solve the issue. Disputes concerning farm boundaries occurred when a farmer encroached on a farm adjacent to his [15].). Finally dispute that happen on farmland, are lending a piece of farmland to a person for the purpose of only cultivation with the short period of time usually during the rainy season, there is land which are called (Xamiir) and only cultivated in this period, sometimes it happens that, the person may argue later that he belongs the farm, this lead dispute between the two persons.

\subsubsection{Women Related Conflict}

Members of the focus group discussion have outlined conflict, occur related with women especially in the rural area where pastoralist resides, women conflict happens in several ways among Degodia clan at first, girl's marriage without consent of her father or her brothers is very sensitive and causes conflict when it happens without their grant. If a girl marries man without knowing her parent, then it may create a problem because they may refuse the marriage. The FGDs also adds that it is not related with cultural but may be the two families, have inherited with their grand parent or have dispute that occurred previously. If the family man accepts the mistake first, they should bring Sabeen Xir (the first interaction with the girl family) if they reject the marriage proposal, then it may create dispute with the two families and further leads to intra-clan conflict.

The second source of conflict related with women is when parent give their daughter to a man without her consent, because the parent has right to choose the husband of their daughter. Sometimes the girl may refuse to such offers and go with the man of her choice while the first offer of the man 
is there; this may lead to a dispute between her family and the family of the man of her choice.

According to elders, conflict happens when women husband dies (widow) and when she refuses to marry her husband brother or his close relatives. If she refuses to marry all the resource, she has been ordered to transfer to her died husband's family and her relatives will inform if they can solve a dispute. If the dispute is not solved, conflict may arise between the families. In addition to this sometime when the youth fought in the weeding, traditional gathering dance and other cultural meeting, women may sing ill songs that provoke the conflicting parties of different sub-clans.

\subsubsection{Water as Source of Conflict}

The data obtained through interview conducted with elders, mentioned in the most important and highly rated cause of conflict in the area is related to water point access. This has to do with natural changes factors including drought. This in effect catalyzes the competition over scarce resources, especially during droughts and dry seasons when the nutritional conditions of livestock are generally uncompromised. The limitations of the water resources and the subsequent competition over it often led to violent conflicts between different clan and sub-clans of Degodia pastoralist roaming in the study areas. In times of prolonged dry season and drought years the pastoralists move from one place to another place in search of water points. Hence, conflicts over water access become common. This result is in consistent with the study made by Gedi (2005) indicates that the grazing land of Degodia pastoralist is characterized by serious moisture stress and poor-quality pasture due to prolonged dry seasons and water points including traditional water wells completely dry up. As a result, Degodia pastoralists with their livestock move to the neighboring grazing and watering points which leads to conflict. According to respondents, though historically there have been a tradition of cooperation for access and use of water points and grazing land, particularly in times of serious drought due to strong neighboring cooperation related to drought-cycle management currently this condition is becoming as source of conflict.

According to the key informants of interview, the major water source for the Degodia pastoralist are Dawa and Ganele River and wells that are found in the distance place. As far as water it is free for use but what causes dispute related with the water access point among the Degodia pastoralist is how to share water and who should use first. This mostly occurs during the dry season when there is scarcity of water. This result supports the study made by Mohamed, A. M., which indicates that during harsh or drought time, people converge on places with water, wells, and rivers this leads to arguments and disputes concerning how to share water and who should drink first [15].

\subsubsection{Wells as Source Conflict (Ceel)}

According to the key informant's interview, Ceel is important water source used by the Degodia pastoralists clan both during the rainy seasons and early parts up to the mid of the dry seasons. It is a shallow well, that members of the family dug together and have a common ownership at family. The ownership of the Ceel is mostly personally owned or at family level ownership as the available labor and material at family level could enough in digging this type of water source. Conflict that arise due to the wells (Ceel) are also found in the study area usually when digging or excavating privately, if they are dug closely it might happen that one might have more water than the other, due to this reason it causes conflict. When digging the well (Ceel) they should have distance of thirty meters between wells.

\subsection{Indigenous Conflict Resolution Among the Degodia Clan}

There are a number of traditional conflict resolution mechanisms used by the pastoralists in Somali region, including traditional conflict management mechanisms utilized and still quite instrumental today in some situations. This system is the broadly and popularly referred traditional conflict resolution system called the xeer system? In the following paragraphs important aspects of the system have been discussed taking the case of the role of the Wabar and the Guurti systems among the Degodia Somali pastoral clan in Dollo District.

\subsection{The Degodia Wabar System}

According to data gained from key informant interview, Wabar system is one of the most popularly used traditional jurisprudence and conflict resolution, leadership system applicable among the Degodia clan. Wabar is a title given to the leader of this clans. The Wabar is the king of Degodia clan and are selected from one of clan of Degodia called Abrisha clan. The wabar functions based on succession, so to be a successor of the Wabar, the person should be the son of the former king (Wabar), and the former Wabar must indicate or mention his successor with especial testimonials and the successor must have indications of testimonials made by his father (Wabar). Other important condition related to the inheritance of the kingship has to do with the mother of the wabar's children eligible for inheritance is born from. That the child should be born from mothers who belong to a subclan called Gabow. In addition to this age of the wabar should be Forty years in order to be the proper inheritor of wabarship.

Upon fulfilling all the aforementioned and other criteria's the member of the Degodia clans give to the clan of the wabar (Abrishe) one hundred camels. These camels are given to avoid the claim that that the King belongs to his sub clan alone but the wabar represents and belongs to all Degodia clan, not to especial clan, coronation of the Degodia king is made through preparation of a big event and festive. In this inauguration ceremony all clans of Degodia are invited and come to assembly under a big tree. The neighboring clans and government officials are also invited during the ceremony and he becomes the Wabar (King) of Degodia, wabar is highly respected among the Degodia wherever they live in Ethiopia, Somalia, Kenya, and every member of 
Degodia clan member obeys his order.

\section{(i) The Wabar in Conflict Resolution}

According to interview conducted to the elders, one of the most important and dominant and highly applicable traditional conflict resolution institutions among the Degodia clan is the wabar system. In the conflict resolution process, the Wabar involves and solves any kind of dispute that arises among the Degodia clan and also conflict with their neighboring clans. The wabar system functions based on the functional structure it has developed overtime. The wabar system has a council that consists of fourteen persons called (Guurti Wabarka). Members of this council are selected from the ten sub-clans of Degodia. The council thus involves in conflict resolution process and work with the Wabar on the overall affairs of the clan.

The Wabar has a speaker and a secretary who are selected from the Guurti, when conflict occurs among the Degodia clans the Wabar sends Guurti to the conflicting parties, and then they see the issue and try to solve the problem. If the disputant parties concerned do not accept the Guurti decision, then it goes up to the higher place. Then they are given an appointment to meet with the Wabar. Whereupon appointment is made either the Guurti members go to see the Wabar or the Wabar comes to the specified venue of meeting. During the meeting the Wabar listens the issues from the Guurti members and sees how the Guurti solved the problems. If he feels dissatisfaction about the decision, they reached about issues to solve the problems, he orders again to be conducted another discussion to solve the issues, and then they bring back the result to the Wabar for final decision.

\section{(ii) The Guurti in Wabar System}

Based on the elders interview the Guurti are the council of elders that are selected from each clan of Degodia. The selection of Guurti members have certain criteria which is considered first, each clan is informed to bring one person that can serve as the Guurti member, then the clan chooses that person on the bases of his cultural knowledge, ability of speech or oratory (cod kar), religiously, honesty and experience that he participated previously in conflict resolution and these persons are given one hundred goats by their sub-clans as support, since they are working on affairs of the sub-clan. The role of the Guurti members is to solve any dispute that occurs among the Degodia clans and subclan and usually to perform other tasks within them.

Whenever conflict happens, the Guurti goes to that place. First, they work for stopping of conflict, then they call the disputants to forward their complaints turn by turn, and the Guurti also summons neighbors that are not part of the conflict in order to collect their testimony. After the Guurti receives the information, the elders of the disputants and the others who are not part of the conflicting parties share the information. According to Gedi then the Guurti identifies the wrong doer and pass their final discussion (17).

When the clan selects the one who represent them in to the Guurti institution, there is also another person that is supposed to work with him for affairs of the sub-clan. That means if the clan is divided into five sub-sub-clans, then each of them will have one person that represent them. The role of the latter is to solve minor cases happening within the subsub-clans. Anything that is needed from the sub-clans is their duty to collect, and if conflict occurs within the sub-clan, then the Ugaas, his deputies and some knowledgeable elder from the sub-clan solve it.

\section{(iii) The Role of Religious Leaders in Conflict Resolution}

Religious leaders (Ulamaudin) play a crucial role in restoring peace. If any one of the conflicting parties refuses to stop the fight, it is the role of the religious leaders to convince them and bring them to the tree for negotiation. In the study area, it is strongly believed that disobeying the ulamaudin causes curse or Habar as they call it locally It is believed that at the end of the conflict the clan that accepted the solution of the ulamaudin will get the upper hand over the one that has turned it down. In addition, if a conflict causes only physical injuries, it is the role of the ulamaudin to decide the compensation that has to be paid for the victim by referring to the Sharia law. Any disputes that are related to marriage, divorce, and inheritance are usually resolved by the religious leaders.

\subsection{Challenges of the Degodia Indigenous Conflict Resolution}

According to the key informants, the challenges that the Degodia conflict resolution faces are that logistic problem. Whenever conflict arises the elders are supposed to go where the conflict occurred in this case the elders face financial problem since there is no resource that are allocated to them and is supposed to be collected from the clan and this may take time. Another challenge of the Degodia indigenous conflict resolution is that like the other Somalis the Degodia xeer is not written but is memorized by the elders and passed from generation to generation. Because of the unwritten nature of the xeer, its knowledge is confined to elders only.

On the other hand, there is a propensity of favoring the socalled modern institutions by the younger generation. Nowadays there is a gap that is being created between the old and young generations. The knowledge of the xeer is limited to elders residing in rural areas. These elders send their children to urban areas where education facilities are based. The children grow up in a different mind-set and when they grow up consider themselves as modernized and their parents as traditional and backward. This leads to gradual die away of the xeer and eventually indigenous institution.

This creates confusion as to who the legitimate elders are. It also seriously undermines their authority and legitimacy particularly in conflict resolution. The sustainability of the indigenous institutions is unquestionable at least in the short run. As the Somali society is anchored to the clan system, the acceptability and legitimacy of the customary institutions will remain as intact as it is. The weak representation of the regional government in most pastoral area of the Woreda leaves no chance for the only effectively working institution to collapse easily.

However, in the wake of globalization and increased 
urbanization, the elders forecasted less acceptability and gradual fade out of traditional institutions in the future. As to them, this is caused by many interrelated reasons. For example, shift is occurring in urban areas; from traditional to modern institutions for conflict resolution. In addition, modernization of the younger generations leads to preferring modern institutions of conflict resolution. The number of elders who are experts of the xeer is decreasing through time. As there is no mechanism in which the younger generation is taught the basic principles of the xeer. No effort whatsoever is being made by different sections of the community including the government to conserve the xeer.

\section{Discussions}

According to this study the data obtained from the elders, discussed over farmland ownership dispute, and farm border related issue occur among the Degodia clan. This finding is more or less similar to study conducted in southern Ethiopia showed that land dispute was cause of conflict among these communities $[1,16]$. The similarity may be community structure and scare farming land.

Another finding of this study was women as cause of conflict in this community, Members of the focus group discussion has outlined conflict occur related with women especially in the rural area where pastoralist resides, women conflict happens in several ways among Degodia community at first, girl's marriage without consent of her father or her brothers is very sensitive and causes conflict when it happens without their grant. Another study which was conducted in the study area also show that women related conflict happens in different ways among the Degodia community and women as cause conflict [17].

Based on information obtained from elder, ceel is important water source used by the Degodia community both during the rainy seasons and early parts up to the mid of the dry seasons. They mentioned that the most important and highly rated cause of conflict in the area is related to water point access. Conflict that arise due to the wells (ceel) usually happens when digging or excavating privately, if they are dug closely it might happen that one might have more water than the other, due to this reason it causes conflict, when digging the well (ceel) they should have distance of thirty meters between wells. This result is consistent with the study made by [17]. indicates that the grazing land of Degodia pastoralist is characterized by serious moisture stress and poor-quality pasture due to prolonged dry seasons and water points including traditional water wells completely dry up.

As per information gained from key informant interview, Wabar system is one of the most popularly used indigenous conflict resolution, leadership system applicable among the Degodiya community and "Wabar" is a title given to the leader of this community. According to [18] traditionally, Somali communities are ruled by elders and have structures for conflict mediation, transformation and resolution through councils of elders Guurti Members.
According to focus group discussion the Guurti are the council of elders that are selected from each clan of Degodia. The selection of Guurti members have certain criteria which is considered first, each clan is informed to bring one person that can serve as the Guurti member, then the clan chooses that person on the bases of his cultural knowledge, ability of speech or oratory, religiously, honesty, age, dignity, and experience that he participated previously in conflict resolution. According to some studies conducted in different parts of Ethiopia agreed that the selection of the elders is drawn from all levels of the community and was usually a man who gains religious knowledge and power of oratory and experience $[2,16,18]$.

Religious leaders (Ulamaudin) play a crucial role in restoring peace. If any one of the conflicting parties refuses to stop the fight, it is the role of the religious leaders to convince them and bring them to the tree for negotiation. In addition, if a conflict causes only physical injuries, any disputes that are related to marriage, divorce, and inheritance are usually resolved by the religious leaders. Similar study shown Ambo District in Oromo region that religious leaders are visible as other actors in resolving conflict both intra and inter clan conflict, the community considers religions leaders as those who can act on behalf of the will of God [2].

Based on information obtained from the key informants, the challenges that the Degodia conflict resolution faces are logistic problem, Degodia indigenous conflict resolution is not written but is memorized by the elders and passed from generation to generation. Some other studies also found that indigenous knowledge systems in Ethiopia including conflict resolution is oral in nature, not systematically documented and decisions are often not recorded [19, 20].

\section{Conclusion and Recommendations}

\subsection{Conclusion}

Finding of the study shows the sources and drivers for conflicts in the study areas generally can be categorized into three places. These are conflict related to farmland, water point's access, and women.

The findings also show that indigenous institutions enjoy high acceptability and Legitimacy when it comes to conflict resolution. People usually turn to indigenous institutions whenever conflict arises. Religious leaders have a role to play particularly in bringing ceasefire and stopping hostility and it is the role of the religious leaders to convince them and bring them to the tree for negotiation.

The study found that the Degodia indigenous institution faces some challenges the indigenous conflict resolution faces is logistic problem. indigenous of conflict resolution is not written its knowledge is confined to elders only.

\subsection{Recommendations}

Overall, to advance traditional conflict resolution system by improving its shortcomings, the following can be taken as chief ingredients of recommendation. 
a) Governmental and non-governmental bodies should work with not only by approaching the clan leaders, but also by educating the ordinary section of the community so as to get the acceptance of all stakeholders and so as to drain the conflict from its sources.

b) To overcome the possible decline of knowledge of customary (xeer) and its legitimacy among the young generation, the Somali region educational curriculum need to be designed in such a way that enables the younger generations to grow up appreciating their culture and enabling them advance their knowledge of xeer.

c) Elders have to share their knowledge of solving traditional conflict resolution to the young generation and thereby they can replace the elders when they die or at the time of inconvenience.

\section{References}

[1] Mengesha, A. D., S. S. Yesuf, and T. J. A. J. o. E. R. Gebre, Indigenous conflict resolution mechanisms among the Kembata society. 2015.3 (2): p. 225-242.

[2] Muchie, Z. and E. Bayeh, Traditional Conflict Resolution Mechanisms among Ambo Woreda Communities. Journal Political Science Publication Aff, 2015. 3: p. 1.

[3] Miller, C. A. and M. E. King, A glossary of terms and concepts in peace and conflict studies. 2005: University for peace San Jose, Costa Rica.

[4] Berhane, Y., Mezard, indigenous conflict resolution mechanism in northern Ethiopia: Assessing rural alamata woreda, Tigray regional state, Ethiopia. 2014: Anchor Academic Publishing (aap_verlag).

[5] Fiseha, M., PHd Dissertation on the Topic: Traditional Conflict Management and Resolution Mechanisms: The Case of Shako People in Ethiopia. 2018, Addis Ababa University.

[6] Gulliver, P. H., Disputes \& negotiations: A cross-cultural perspective. 1979: Academic Press.

[7] Kennedy, M., Ambivalent Indigeneity, in Striding Both Worlds. 2011, Brill Rodopi. p. 155-203.

[8] Osi, C. J. C. J. C. R., Understanding Indigenous Dispute Resolution Processes and Western Alternative Dispute Resolution, Cultivating Culturally Appropriate Methods In Lieu Of Litigation. 2008. 10: p. 163.
[9] Mekonnen, D., Major Features of Indigenous Conflict Resolution Mechanisms in Ethiopia. International Journal of Arts Humanities and Social Sciences (IJAHSS), 2016. 1 (1).

[10] Brock-Utne, B., Indigenous conflict resolution in Africa: A draft presented to the week-end seminar on indigenous solutions to conflicts held at the. Oslo: University of Oslo, 2001.

[11] Mengesha, A. D., "The Role of Sidama Indigenous Institutions in Conflict Resolution: In the Case of Dalle Woreda, Southern Ethiopia”. American Journal of Sociological Research, 2016. 6 (1): p. 10-26.

[12] Bouh, A. M. and Y. Mammo, Indigenous conflict management and resolution mechanisms on rangelands in Somali Regional State, Ethiopia. Nomadic Peoples, 2008: p. 109-121.

[13] Temin, J., Grassroots conflict assessment of the Somali Region, Ethiopia. CHF International, 2006.

[14] CSA, 2007 Population and Housing Census of Ethiopia: Results for Somali Region. Ethiopia and Calverton, Maryland, USA: Central Statistical Agency and ICF International, 2015.

[15] Mohamed, A. M., The role of Somali women in the search for peace. Women and peace in Africa: Case studies on traditional conflict resolution practices, 2003: p. 75-110.

[16] Wolde, B. G., Traditional Conflict Resolution Mechanisms in Kaffa Society of Ethiopia. Üniversitepark Bülten, 2018. 7 (2): p. 128.

[17] Gedi, A. A., Herder-farmer conflicts in the Dawa-Ganale river basin area: the case of intra-clan conflict among the Degodia Somali of Dollo Ado district in the Somali regional state of Ethiopia. Bern: NCCR North-South, 2005.

[18] Jibril, S. M., Intra-Clan Conflict between Ida'gale and Habaryonis and the Role of Traditional Leaders in Pastoral Conflict Resolution in Aware District, Somali Region of Ethiopia. Asian Journal of Humanities and Social Studies (ISSN: 2321-2799), 2013. 1 (03)

[19] Alemie, A. and H. Mandefro, Roles of Indigenous Conflict Resolution Mechanisms for Maintaining Social Solidarity and Strengthening Communities in Alefa District, North West of Ethiopia. Journal of Indigenous Social Development, 2018. 7 (2).

[20] Mengesha, A. D., S. S. Yesuf, and T. Gebre, Indigenous conflict resolution mechanisms among the Kembata society. American Journal of Educational Research, 2015. 3 (2): p. 225-242. 